\title{
0 impacto indelével do Ressuscitado: a experiência da ressurreição em James Dunn
}

\section{The lasting impact of the Risen One: The resurrection experience in James Dunn}

\section{El impacto indeleble del Resucitado: la experiencia de la resurrección en James Dunn}

\author{
Henrique Mata de Vasconcelos* \\ Submetido em: 19-6-2021 \\ Aceito em: 8-9-2021
}

\author{
* Faculdade Jesuíta de Filosofia e Teologia \\ - Belo Horizonte \\ Doutorando em Teologia Sistemática \\ E-mail: henriquemata97@hotmail.com
}

\begin{abstract}
RESUMO
A ressurreição de Jesus é comumente tratada, simples e diretamente, de maneira objetivista (fisicista) ou subjetivista. O objetivo do presente artigo é, levando em conta o estado emocional dos seguidores do Nazareno mediante a sua morte e o imaginário religioso escatológico, identificar o que teria sido as aparições experienciadas pelos primeiros cristãos. Com esse propósito, iremos dialogar com o segundo capítulo da pesquisa de James Dunn acerca das experiências religiosas de Jesus e dos primeiros cristãos refletidas no Novo Testamento, que trata sobre os relatos das aparições e as experiências contidas nesses. As aparições de Jesus, após a sua morte, vivenciadas pelos seus seguidores e perseguidor (Paulo), causaram um impacto que marcou não apenas a vida deles, mas também toda a história.

Palavras-chave: Escatologia; experiência religiosa; comissionamento; percepção visionária.
\end{abstract}

\begin{abstract}
Jesus's resurrection is commonly and simply treated in an objectivist (physicist) or subjectivist way. This article has as the objective, taking into account the emotional state of Nazarene's followers after his death and the eschatological religious imaginary, to identify what would have been the appearances experienced by the first Christians. With this intention, we will dialogue with the second chapter of James Dunn's research about the religious experiences of Jesus and the first Christians as reflected in the New Testament, which deals with the appearances accounts and the experiences presents on these. Jesus' appearances after his death, experienced by his followers and persecutor (Paul), caused an impact that marked not only their lives but also all the history.

Keywords: Eschatology; religious experience; commissioning; visionary perception.

\section{RESUMEN}

La resurrección de Jesús es comúnmente tratada, simple y directamente, de manera objetivista (fisicista) o subjetivista. El objetivo del presente artículo es, teniendo en cuenta el estado emocional de los seguidores del Nazareno, a partir de su muerte y del imaginario religioso escatológico, identificar lo que habrían sido las apariciones experimentadas por los primeros cristianos. Con este propósito, vamos a dialogar con el segundo capítulo de la
\end{abstract}


investigación de James Dunn acerca de las experiencias religiosas de Jesús y de los primeros cristianos reflejados en el Nuevo Testamento, que, específicamente, trata sobre los relatos de las apariciones y las experiencias contenidas en ellos. Las apariciones de Jesús, después de su muerte, experimentadas por sus seguidores y perseguidor (Pablo), causaron un impacto que marcó no solo sus vidas personales, sino también toda la historia.

Palabras clave: Escatología; experiencia religiosa; comisionamiento; percepción visionaria.

\section{Introdução}

O cristianismo tem como um de seus pilares a tradição da ressurreição de Jesus, ao lado da do Pentecostes. De forma surpreendente e curiosa, um bando de indivíduos frustrados se tornou fundador dessa religião extensa e diversa. Como teria surgido essa tradição e a crença nela, e porquê ela foi e ainda é anunciada pelos cristãos com tanta convicção são questões que pretendemos percorrer e encontrar.

Segundo Paulo Nogueira (1963, p. 61), essa tradição é

discreta e elegante. Não há relatos fantasiosos e ufanistas de luzes e manifestações sobrenaturais no túmulo de Jesus. Tampouco há uma descrição de um cadáver voltando à vida. Esse exibicionismo, que flerta com a incredulidade, não faz parte do repertório de seus seguidores. O que encontramos é a visão e o anúncio do túmulo vazio feito pelas mulheres. E depois temos uma série de relatos sobre encontros com o ressuscitado.

Nogueira também nos relembra que é a partir da experiência religiosa de algumas mulheres de classe baixa e analfabetas, da periferia do Império Romano, que surge o anúncio fundante do cristianismo e o silêncio é quebrado. Segundo ele, uma vez que possui a pretensão de anunciar a revelação e a presença de Deus e do seu reino entre os seres humanos, com o seu triunfo sobre a opressão e a morte, isso faz com que ele seja, desde o princípio, uma religião de paradoxos (NOGUEIRA, 2020, p. 59).

O relato mais antigo que temos do túmulo vazio encontra-se no Evangelho de Marcos (16,3-8), ${ }^{1}$ em que Maria de Magdala e Maria, mãe de Tiago e Salomé, não encontram o corpo de Jesus, mas um jovem que tinha como vestimenta uma túnica branca. Esse jovem anuncia que ele ressuscitou e que encontrará os discípulos na Galileia e elas, com temor e estupor, fogem. "Como pode um evangelho terminar com a fuga assustada e desesperada das mulheres? Por que as mulheres reagiram com medo ao anúncio do anjo? Tratava-se de uma visão?” (NOGUEIRA, 2020, p. 59-60).

\footnotetext{
1 Conforme Nogueira (2020, p. 60), "segundo os melhores manuscritos, esse evangelho termina com essa expressão de medo e de desespero das mulheres. Nos demais evangelhos há relatos de aparições e encontros com o ressuscitado, que depois são resumidas e acrescentadas no Evangelho de Marcos em outros manuscritos, em uma tentativa de harmonizá-lo com os outros evangelhos e de tirar o tom dramático, e até constrangedor, do final mais antigo".
} 
Adjacente à experiência dessas mulheres e desse relato, levantamos um outro ponto. É da experiência de Paulo que surge a sua teologia. Citando Hermann Gunkel (1862-1932), é isso que James Dunn (1939-2020) assume. Tomando como exemplo a crença de Paulo no Espírito e afirmando que ela nasce do que ele havia experienciado dele, o teólogo defende que novas religiões nascem e antigas crenças renascem de experiências assim, citando como exemplo homens como Maomé, Lutero, George Fox e John Wesley (DUNN, 1997, p. 4, itálico do autor). Se ele está correto, como julgamos e estamos certos que sim, é mais que relevante investigar a(s) experiência(s) da(s) qual(is) nasce a tradição da ressurreição de Jesus, buscar entender a(s) vivência(s) fundante(s) do anúncio que ele havia ressuscitado e estava vivo.

Tendo isso em vista, é com esse fim de compreender as diferentes experiências que deram origem à essa tradição que iniciamos o nosso estudo. Entretanto, à vista disso, primeiro veremos o estado dos discípulos após a morte de Jesus. Segundo, iremos nos aproximar do imaginário escatológico do ambiente vital dos primeiros cristãos, no qual surge a crença na ressurreição. Terceiro, em diálogo com James Dunn, pretendemos entender as experiências e os relatos das aparições do Ressuscitado presentes no Novo Testamento. Quarto, faremos algumas reflexões teológicas acerca da ressurreição concernentes ao corpo de Jesus.

\section{A devastação do movimento de Jesus e do projeto do reino}

Gerhard Barth (1927) afirma que, para que as respostas dos discípulos de Jesus diante de sua morte sejam compreensíveis, precisamos entender a condição deles diante dela. Essa morte é um fato histórico, um dos mais comprovados pela pesquisa sobre Jesus, e é certo que eles não estavam preparados para ela, principalmente pelo fato de que ele morreu de forma insultuosa no madeiro da maldição. Assim, sendo confrontados com a prisão e condenação de Jesus, e com a sua execução, eles entraram em uma profunda crise, em um conflito que também era de fé (BARTH, 1997, p. 14-15).

Nogueira concorda que eles não estavam preparados, afinal os discípulos e seguidores de Jesus esperavam, com a sua ida a Jerusalém, o princípio do reinado de Deus. Essa esperança de um novo tempo ainda foi aflorada com o ato simbólico que Jesus realizou no Templo, de purificar aquele lugar. "A vinda do Filho do Homem e o juízo final eram aguardados para aqueles dias (para 'esta geração', conforme Marcos 9,1 e 13,30) e não para um futuro distante" (NOGUEIRA, 2020, p. 57).

Por causa disso, eles ficaram chocados com os acontecimentos que se sucederam. A expectativa deles pelo fim dos tempos e pelo juízo escatológico, 
pela intervenção de Deus, não foi preenchida. Tudo continuou como era, os ímpios e opressores ainda detinham o poder, havia um silêncio divino e o reino que era desejado e anunciado não se concretizou. Então eles se dispersam e fogem, abandonando o seu líder. Somente as mulheres não o abandonaram (NOGUEIRA, 2020, p. 57).

Conforme Barth (1997, p. 15), é improvável que a fuga dos discípulos após Jesus ser preso (Mc 14,50; Mt 26,56) seja uma invenção da primeira comunidade. Sendo pouco elogiosa, essa referência não se encontra em Lucas. Mesmo com Pedro seguindo à distância Jesus e os soldados que o levava cativo, até o pátio do palácio que pertencia ao sumo sacerdote (Mc 14,54), a fuga dos seguidores de Jesus diante do seu aprisionamento nos mostra claramente que eles viram a sua causa como perdida. Eles retornam à Galileia e alguns até voltam a exercer a atividade pesqueira de outrora (Jo, 21,1-4) e, por causa disso, as primeiras aparições ocorreram na Galileia (Mc 14,28; 16,7), e não em Jerusalém. O significado direto desse abandono e retorno à sua terra é que eles perderam a esperança em Jesus e desistiram de sua causa. Ainda, o estado de espírito dos discípulos, perante morte de Jesus, pode ser visto na resposta dos discípulos de Emaús (Lc 24,21). Nela vemos que "a esperança que tinham depositado em Jesus havia se quebrado". Segundo Nogueira (2020, p. 62), ao relatarem o túmulo vazio, esses dois discípulos não são capazes de compreender e nem de tirar alguma conclusão sobre o que houve.

Sabemos então que "o escândalo do messias morto injustamente lançou os discípulos em decepção, agonia, desespero e solidão. [Havia uma] absoluta falta de sentido" (NOGUEIRA, 2020, p. 62-63). A morte de Jesus os deixou em um estado de aporia, de sofrimento e de divagação. Os discípulos estavam enfrentando mais uma tempestade que, agora, era existencial. Estavam à deriva em relação à vida e ao Reino, sobretudo no tocante à esperança, à fé e ao propósito.

Conforme Barth, esse colapso da esperança e da fé se deu porque eles não esperavam o que se sucedeu. Em suas tradições religiosas, tanto na expectativa judaica da época quanto no Antigo Testamento, um messias que sofresse e morresse não era aguardado. Pelo contrário, aguardavam um messias político, que poderia ser também um messias sacerdotal (Qumran), além de um Filho do homem vindo do céu para julgar a terra. Devido às suas expectativas e falta de sentido que haveria uma morte assim, "os discípulos não estavam ou pelo menos não estavam suficientemente preparados para o que iria acontecer" (BARTH, 1997, p. 17). Para Barth, mesmo se os discípulos tivessem tentado compreender a morte de Jesus na cruz a partir de sua proclamação, é improvável que eles estariam preparados (BARTH, 1997, p. 20). 
Geza Vermes (1924-2013) lembra de passagens em que os evangelistas relatam a incompreensão dos discípulos em face das predições de Jesus sobre a sua morte e ressurreição, como demonstra a reação de Pedro (Mc 8, 31 33; Mt 16,21-23), entre outras. Algumas narram o anúncio e incompreensão relacionadas à paixão (Lc 9,44-45), outras também mencionam a ressurreição (Lc 18,31-34; Mc 9,10.31-32). Para ele, essas passagens são extravagantes. Entretanto, uma vez que os Evangelhos mostram que a prisão, crucificação e ressurreição de Jesus foram inesperadas, eles provam que essas passagens não são autênticas, pois se fossem os discípulos e apóstolos estariam totalmente certos do que se sucederia (VERMES, 2013, p. 98-103).

A cruz e a ressurreição foram inesperadas, desconcertantes, com efeito, incompreensíveis para os apóstolos. Quando Jesus foi capturado no jardim do Getsêmani, seus apóstolos o abandonaram e fugiram, pelo menos segundo o testemunho dos evangelistas sinópticos. Pedro chegou até a negar que tinha conhecido Jesus. Quanto à ressurreição, ninguém esperava por ela, e os apóstolos tampouco se mostraram propensos a acreditar na boa-nova trazida a eles pelas mulheres que tinham visitado o túmulo de Jesus. [...] é muito pouco provável que o comportamento desonroso dos apóstolos não corresponda à realidade e seja mera invenção (VERMES, 2013, p. 102).

Ainda a respeito da reação dos seguidores de Jesus, Barth afirma que:

Mesmo que Jesus tenha apontado para a sua morte iminente, ${ }^{2}$ a atitude dos discípulos

2 Para Geza Vermes (2013, p. 102-103), “as predições de Jesus sobre a sua morte e ressurreição e sua referência a profecias bíblicas sobre o seu sofrimento e glorificação são inautênticas. Elas parecem representar a reconstituição retroativa até Jesus de algumas das armas do arsenal apologético-polêmico da Igreja judaico-cristã". Entretanto, conforme reconhece Barth, "é perfeitamente provável que Jesus devesse contar com um agravamento do conflito com líderes religiosos do seu povo até o ponto de sofrer uma morte violenta. Apontaram para isso, com razão, Heinz Schürmann e outros. Por ter diante dos olhos o fim violento de João Batista e por ter ele mesmo entrado repetidamente em graves conflitos com os líderes religiosos do seu povo, Jesus, a rigor, tinha que contar com um fim violento para si mesmo. Afinal, sua morte na cruz não pode ser separada de sua atitude e proclamação anteriores. Quem proporciona a graça e o perdão de Deus aos pecadores independentemente do serviço no templo, quebra o sábado, abole as leis de pureza e, assim, questiona a lei, deve contar com a possibilidade de que esta mesma lei, por parte dos líderes religiosos de Israel, se voltaria com todo o seu rigor contra ele. Isso tudo é válido mesmo que os anúncios de sofrimento e ressurreição do Evangelho de Marcos, adotados e ampliados por Mateus e Lucas, possam ser atribuídos, no máximo, a uma tradição comunitária pré-marquina, mas decerto dificilmente ao Jesus histórico" (BARTH, 1997, 23-24). A afirmação de que os prenúncios de Jesus acerca da sua morte são inautênticos não é sólida. É bem plausível e também presumível que Jesus tenha visto a morte se achegando e que tenha compartilhado essa sua aflição, o seu cálice, com os seus discípulos, a despeito da incompreensão e confusão deles. Assim, é plausível e provável que os prenúncios de sua morte sejam ecos de suas palavras, mesmo se não forem sua ipsissima verba (palavras exatas) e se os seus seguidores não compreenderam esses presságios. A parábola dos vinhateiros (Mc 12,1-12) e passagens como Mc 8,31; 9,12.31; 10,33-34; 14,21.41; Mt 
mostra que, pelo visto, eles não captaram realmente tais anúncios: reagiram de modo totalmente atônito à prisão e morte de Jesus; todas as esperanças que tinham depositado em Jesus haviam-se destroçado. A reiterada ênfase marquina na incompreensão dos discípulos diante dos anúncios de sofrimento de Jesus tem, portanto - não obstante a intenção teológica redacional nela contida -, de fato também um pano de fundo histórico: os discípulos mostraram não estar preparados para tal fim de seu mestre (BARTH, 1997, p. 24).

É verdade que a ressurreição era uma crença comum no tempo de Jesus, conforme veremos posteriormente. Entretanto, conforme esclarece N. T. Wright (1948), "nenhum judeu supunha que o Messias ressuscitaria da morte, pois nenhum judeu imaginava o Messias morrendo como parte de sua vocação" (WRIGHT, 2011, p. 445, tradução nossa).

Perante o exposto, compartilhamos das afirmações de Nogueira (2020, p. 58) de que "o cristianismo nasceu de uma experiência de solidão e desespero" e de que "a solidão, a tristeza e o desespero, após a morte do messias, são o ponto de origem dos encontros que se darão". É na desolação que se encontrava o estado existencial dos seguidores de Jesus e, no meio dessa situação, eles experienciam encontros com o mesmo homem que havia morrido, eles vivenciam as aparições do Ressuscitado.

Conforme Barth, é esse cenário que explica a centralidade dos acontecimentos da páscoa para a fé e para o nascimento da comunidade cristã. A grave crise dos discípulos, causada pela morte injuriosa de Jesus é ultrapassada com as aparições pascais. "Por esta razão a confissão da ressurreição de Jesus torna-se a afirmação central da primeira cristandade" (BARTH, 1997, p. 16). Foram elas que renovaram a fé dos discípulos desolados, pois apesar da ultrajante paixão, com as aparições eles estavam seguros de que Jesus era de fato o salvador esperado, dado por Deus. "A ressurreição de Jesus lhes mostrou que Deus havia tomado partido do crucificado e o legitimado como o salvador" (BARTH, 1997, p. 24).

O grupo de indivíduos que deram origem ao cristianismo passaram por uma profunda transformação. De covardes, desamparados e vazios de

\footnotetext{
26,2; Lc 13,31-33; 17,25; 24,6-7 podem e devem ser lembranças dos discípulos de Jesus, mesmo e se foram reinterpretadas após a Páscoa. É bem claro que Jesus, com o decorrer de seu ministério, viu a sua morte se aproximando, ainda que incompreendido pelos outros. Tantos relatos dessa tradição só podem ecoar um traço característico dele. É bem provável que as predições de Jesus a respeito de sua ressurreição sejam elaborações teológicas pós-pascais. Entrementes, provavelmente Jesus tinha alguma esperança escatológica, alguma expectativa apocalíptica de uma intervenção divina, mesmo que não esperasse a sua própria ressurreição. O seu grito de abandono demonstra tanto a sua desilusão e frustração pela não intervenção divina até ali, quanto a sua confiança ainda em Deus (Mt 27,46; conferir o S1 22). Portanto, desenvolvimentos traditivos e teológicos não estão construídos sobre a areia.
} 
propósito a pessoas cheias de convicção, ousadia e sentido. Prosseguindo, precisamos também compreender o imaginário escatológico no qual os testemunhos das aparições surgiram.

\section{O imaginário escatológico do Segundo Templo}

Antes de compreendermos os relatos das aparições, é preciso perpassar pelo cenário em que surge a crença na ressurreição, o pano de fundo religioso que possuía uma expectativa escatológica muito forte. Nesse sentido, dois aspectos principais se destacam. Primeiro, o intercâmbio cultural e religioso do judaísmo com outros povos; segundo, a opressão sofrida por eles e a expectativa de uma intervenção divina nessa situação.

Elizangela Soares afirma que, por muitos séculos, a morte no pensamento judaico era o fim, o cessamento histórico e relacional do ser humano, o encerramento de tudo e de todas as relações, com a sociedade, com as pessoas e com a divindade. Desse destino, o Sheol, ninguém poderia escapar; era o destino comum de todos. Entretanto, na época do Segundo Templo (515 a.C-70 d.C), essa crença sofre profundas mudanças, com influências da cultura persa em relação à ressurreição e da cultura helênica concernente à imortalidade da alma (SOARES, 2006, p. 31, 45, 71).

Segundo Voltaire (1694-1778), o iluminista francês, a ideia da ressurreição, assim como outras, foram originadas do zoroastrismo. Robert Zaehner (1913-1974), antigo professor de religiões orientais em Oxford, defende que o zoroastrismo e a tradição judaico-cristã possuem similaridades bem profundas, influência essa que foi propiciada pelo contexto histórico de ambas. Para ele, o ceticismo precisa ir muito longe para negar isso (STAUSBERG, 2009, p. 217-218). Logo, a ideia da ressurreição não é uma criação nem do judaísmo e tão pouco do cristianismo, e sim do zoroastrismo. ${ }^{3}$

\footnotetext{
Conforme Soares (2006, p. 49), "no que se refere à escatologia pessoal, a ideia de ressurreição está no centro no zoroastrismo, inclusive a de um grande dia da ressurreição geral. No entanto, o corpo ressurreto dos zoroastrianos não é o corpo presente, mas um outro que entrou em um estado espiritual mais perfeito, chamado ‘o corpo futuro' (tan i pasen), algo como o corpo espiritual (soma pneumatikon) que muito tempo depois Paulo descreverá em 1 Coríntios 15. Gayomart, o homem primordial do zoroastrismo, será o primeiro a ser ressuscitado, seguido por Mashye e Mashyane, o casal primordial, e então todos os outros, todos os justos e todos os pecadores, sendo que estes últimos já teriam sido suficientemente punidos no tempo transcorrido entre sua morte e ressurreição. Esta é uma tradição posterior, na qual mesmo aqueles que preferiram druj [mentira] à asha [verdade] teriam sua segunda chance [num purgatório, o Hamestagan]. Neste contexto, todos serão salvos e a ressurreição dos mortos acontecerá graças à ação de um salvador, Saoshyant ou Soshyans, o último filho póstumo de Zaratustra. Ressuscitando os corpos, a função de Saoshyant é separá-los dos elementos constitutivos que os fizeram decair e reuni-los com suas almas. Diante desse quadro, embora muito resumido, parece-nos razoável
} 
Soares discorda da hipótese que, isolando Israel ou o judaísmo de seu ambiente vital, afirma que a crença na ressurreição foi um desenvolvimento interno do judaísmo. Para ela, seria uma grande coincidência esse desenvolvimento totalmente próprio, sem nenhuma influência da religião que formou as bases da cultura em que os judeus viviam. Segundo a teóloga,

a crença em ressurreição teria significado um desenvolvimento interno no judaísmo, antes que do judaísmo. Com isto queremos dizer que a ideia original pode ter sido externa, adquirindo desenvolvimentos próprios internamente (SOARES, 2006, p. 49-50).

Ao lado dessa troca cultural e religiosa, a situação de opressão vivenciada pelos judeus também está na origem dessa crença na ressurreição no judaísmo do Segundo Templo.

Wright sintetiza bem esse desenvolvimento rumo ao escatológico:

O antigo Israel, celebrando a bondade do mundo presente, colocava um valor bem mais alto na vida corpórea e não elaborou nenhuma descrição detalhada de uma vida após a morte. Mas, conforme os pensadores judeus refletiam nas injustiças presentes, uma nova visão começou a emergir, reafirmando a bondade da existência corpórea ao insistir que Deus, o Criador, iria refazer o mundo e também as pessoas. Essa crença, sugerida nos Salmos (p. ex., 16,10-11; 73,24) e nos profetas (Os 6,2; Is 26,19; Ez 37,114), floresceu plenamente quando as injustiças particulares de perseguição e martírio forçaram a questão: como Deus seria fiel à sua aliança com Israel e com toda a sua criação? A resposta "ressurreição" (por exemplo, 2 Mc 8) era aceita amplamente entre os judeus nos dias de Jesus e ensinado, em particular, pelos fariseus populares, para os quais "ressurreição" fazia parte de uma visão de renovação religiosa e política, naturalmente contestada pelos saduceus aristocratas. Também nesse período, muitos judeus (p. ex., Fílon de Alexandria (20 a.C-50 d.C) tinham abraçado a visão grega de uma alma contínua, desincorporada e imortal (WRIGHT, 2011, p. 444, tradução nossa).

Em contato com a ideia religiosa da ressurreição na cultura persa e, posteriormente, com a ferrenha perseguição sofrida, os judeus passaram a projetar, para além da desgraçada vida, uma esperança por uma vida renovada. Como vemos, e conforme confirma Maria Clara Bingemer (1949), não estava presente no judaísmo apenas uma esperança, aceita e articulada por todos, acerca do futuro (BINGEMER, 2008, p. 120). Porém, a noção da

dizer que o judaísmo tenha sido, de certa maneira, influenciado por esta formulação. Segal afirma que ressurreição não entra verdadeiramente na vida judaica antes dos judeus terem feito contato com a sociedade persa e notará o que ele considera o mais importante e mais interessante candidato a um empréstimo por eles no Yasna 54: 'Os mortos ressuscitarão em seus corpos sem vida”'. Conforme Wright (2011, p. 444), em geral, a ideia de ressurreição era zombada no paganismo antigo, vista ou como impossível ou como indesejada. 
ressurreição era popular e, certamente, bem conhecida pelos contemporâneos e seguidores de Jesus. Podemos encontrá-la na literatura apocalíptica que foi desenvolvida nessa época. ${ }^{4}$

Segundo Dunn, as raízes desse desenvolvimento remontam a textos como Isaías 24 a 27, adição tardia que remonta ao quarto ou terceiro século a.C., e Daniel 12,2, aproximadamente de 165 a.C. Além de citar o verso de Daniel, também cita o verso 19 do capítulo 26 de Isaías, afirmando que esse último é motivo de disputa. A questão é se o texto se refere à restauração da nação, como na visão presente em Ezequiel 37, ou à ressurreição da morte mesmo (DUNN, 1997, p. 117, n. 88, cf. p. 389).

Todavia, assim como defende Soares (2006, p. 55), mesmo sendo uma metáfora, o essencial que podemos apontar nesse texto de Ezequiel (e em Isaías 24-27), para além da intenção teológica, é a linguagem da ressurreição.

Dunn pontua que, inicialmente, o modo da ressurreição não é bem definido, sendo que em textos como Is 26,19 e Dn 12,3 a ressurreição física não é nem explicitada e nem excluída. Todavia, uma ideia mais espiritualizada, presente em imagens como "roupas espirituais" e "vestimentas de glória", ganha destaque em escritos apocalípticos posteriores (II Ed 2, 39.45; I Enoque 62,22-23; 108,16-21)..$^{5}$ Ao mesmo tempo, também há expressões claras em escritos do período da crença na ressurreição física, mostrando que ela também se desenvolveu na apocalíptica judaica. Segundo o exegeta, até certo ponto, certamente isso se sucedeu como uma reação ao dualismo helênico do corpo e da alma, que apresentava-se como uma influência competitiva (DUNN, 1997, p. 117).

Dunn menciona, em especial, os mártires de Macabeus que esperavam uma restauração da vida e dos órgãos físicos (II Mc 7, 11.23; 14,46). Conjuntamente, cita os Oráculos Sibilinos (IV, 181-182.187): “O próprio Deus moldará novamente os ossos e cinzas dos homens e os levantará mortais mais uma vez, assim como eram antes' a fim de que 'todos os que são piedosos vivam novamente sobre a terra"” (DUNN, 1997, p. 117-118, tradução nossa). Por fim, o exegeta ainda aponta que, em II Baruque 49-51, a ressurreição da morte ocorre primeiro e, posteriormente, acontece a transformação da existência à uma forma mais gloriosa. Ou seja, ambas não são simultâneas. Diretamente, ele cita II Baruque 50,26 (DUNN, 1997, p. 118).

Após expor esses textos, Dunn faz uma colocação:

\footnotetext{
4 Para um maior aprofundamento na escatologia judaica e as suas evoluções na literatura apocalíptica, indicamos Soares (2006, p. 55-71, 81-90).

5 Aqui Dunn cita I Enoch 62,15 e 108,11-15. Porém, a referência do mesmo se difere nas versões em português.

6 "Pois a terra, então, certamente restaurará os mortos, [...] ela não fará nenhuma mudança em suas formas, mas conforme ela os recebeu, assim ela os restaurará, e conforme eu os entreguei a ela, assim ela os levantará” (DUNN, 1997, p. 118, tradução nossa).
} 
É provável que foi esse conceito de ressurreição mais cru, menos sofisticado e mais simples que foi tomado pelos primeiros discípulos quando eles tentaram conceitualizar a sua apreensão de Jesus vivo após a morte. Traços de tais visões primitivas são, provavelmente, encontrados em Mt 27,52-53, Jo 5,28-29 e At 2,26-27.31; 13,35-37 (DUNN, 1997, p. 118, tradução nossa).

Com isso, percebemos o ambiente vital no qual os primeiros seguidores de Jesus se localizavam: Por um lado, por causa da morte de Jesus, se sentem fracassados e desiludidos, e o que lhes resta é a fuga à velha vida. Por outro lado, o imaginário apocalíptico da esperança na ressurreição fazia parte das crenças e do imaginário religioso do qual faziam parte. É nesse lugar de encontro, entre o fracasso e o imaginário escatológico, que ocorrem as experiências de encontro e os relatos das aparições. Dialogando com Dunn, buscaremos escrutinar esses relatos, na busca de compreender o que foram essas experiências.

\section{Um diálogo com James Dunn acerca das aparições do Ressusci- tado no Novo Testamento}

Em 1975, Dunn publicou a sua obra Jesus e o Espírito: um estudo da experiência religiosa de Jesus e dos primeiros cristãos conforme refletido no Novo Testamento (Jesus and the Spirit. A Study of the Religious and Charismatic Experience of Jesus and the First Christians as Reflected in the New Testament). As aparições do Ressuscitado ${ }^{7}$ são abordadas no quinto capítulo da obra, o primeiro capítulo da segunda parte. ${ }^{8} \mathrm{Na}$ primeira parte ele estuda a experiência de Jesus, porém não inclui a ressurreição. É provável que seja pela dificuldade de compreender em nível histórico qual teria sido a experiência

\footnotetext{
Optamos por traduzir "resurrection appearances" como aparições do Ressuscitado do que por aparições da ressurreição.

8 A segunda parte de sua obra investiga, primeiro, em dois capítulos distintos, os dois eventos fundantes do cristianismo, as aparições do Ressuscitado (DUNN, 1997, p. 95-134) e o evento do Pentecostes (DUNN, 1997, p. 135-156). Em seguida, trata acerca do entusiasmo presente no princípio do cristianismo (DUNN, 1997, p. 157-196). Com o intuito da nossa pesquisa, nos deteremos na experiência da ressurreição. Contudo, reconhecemos o lugar especial do Pentecostes como acontecimento fundante. Por isso, concordamos, sobretudo em relação ao ápice do impulso e impacto último na vida dos primeiros cristãos, com a afirmação de Dunn: "se algum evento pode ser descrito como o nascimento do cristianismo, esse evento é o que aconteceu no primeiro Pentecostes após a morte de Jesus e as aparições iniciais do Ressuscitado" (DUNN, 1997, p. 193). Ressaltamos que, em graus de importância e primazia, ao lado do Pentecostes do Espírito, estão outros acontecimentos originários do cristianismo: a encarnação, a vida, a morte e a ressurreição de Jesus. Mas certamente, por ser o Pentecostes o evento em que os seguidores e as seguidoras experienciaram um grande impacto e impulso que principiou a seita nascente, podemos considera-lo como o ponto em que o cristianismo nasce.
} 
da ressurreição para o próprio Ressuscitado. Ao contrário da sua experiência do Pai e do Espírito, não há tradições no NT que relatam o que Jesus experienciou existencialmente como Ressuscitado. Nem mesmo temos descrito o processo da ressurreição, conforme nota Nogueira em sua citação presente na introdução. Assim, não dispomos de bases para uma exegese nesse sentido. As aparições do NT são experienciadas pelos primeiros cristãos. Por isso, como Dunn ressalta, aqui Jesus é o "objeto", e não o "sujeito" dessas experiências (DUNN, 1997, p. 95).

Logo depois de apontar as passagens menos sofisticadas das aparições, que teriam herdado o imaginário mais cru da ressurreição, presente no texto de Baruque, Dunn passa a analisar essas, assim como outras que compõem os relatos das primeiras aparições no Novo Testamento. Antes, já havia investigado a experiência de Paulo da aparição. Por fim, o exegeta indaga o que as primeiras testemunhas teriam visto e ouvido. Pretendemos, então, dialogar com o autor acerca dos relatos das aparições e das experiências desses encontros.

\section{No caminho de Damasco: o encontro de Paulo com o Ressuscitado}

Dunn afirma que a documentação de Paulo em 1 Co 15 sobre as aparições nos leva ao começo dos trinta anos misteriosos e obscuros entre a morte de Jesus e a publicação do primeiro evangelho, sendo que ele deve ter recebido essas tradições no tempo da sua conversão ou em até três anos depois (Gl 1,17-18). Elas não tiveram ainda muitos intermediários, pois Paulo conversou com Pedro e Tiago na sua primeira visita a Jerusalém e tinha intimidade com alguns apóstolos. Assumindo que Paulo se converteu em dois ou três anos após a morte de Jesus, 1 Co 15,3-8 nos dá um indício dos primeiros dias da comunidade primitiva. Também, só com ele temos um relato em primeira mão de uma aparição. Paulo afirma ter visto Jesus ressuscitado (1 Co 9,1) e a sua comissão vem com a aparição $(\mathrm{Gl} 1,16)$. Num primeiro momento, a característica distinta da iniciação de Paulo é que Jesus aparece para ele de forma visível e o comissionou aos gentios (DUNN, 1997, p. 97-98).

Porém, as suas cartas sugerem que ele usa a aparição como defesa de sua autoridade apostólica, o que mostra que ela era disputada e que talvez a sua experiência tenha sido contestada. Por isso, surge a pergunta se ele estaria descrevendo uma experiência religiosa mais comum como uma aparição para defender a sua autoridade apostólica. Nesse sentido, a dificuldade de relacionar um relato com outro levanta a mesma questão, pois num ele fala de receber uma revelação em termos de uma verdade sendo descoberta (Gl 
15) e noutro ele fala de ver Jesus (1 Co 15), expressando a sua experiência conforme as aparições eram aceitas. Dunn indaga se Paulo teria expressado a sua experiência de conversão como uma aparição do Ressuscitado por propósitos apologéticos e sem justificação (DUNN, 1997, p. 99).

Lucas parece contestar a descrição de Paulo na estrada de Damasco como uma aparição do Ressuscitado, limitando os apóstolos como os dozes e os definindo como aqueles que não apenas foram testemunhas do Ressuscitado, mas que também andaram com ele. Aliás, ele restringe as aparições aos primeiros quarenta dias. Assim, Lucas descreve a experiência de Paulo como uma simples visão (At 26,19), presumivelmente similar a outras visões que o próprio Paulo fala (como 2 Co 12,1). Logo, Paulo apenas pode ser entendido como apóstolo em um sentido mais simples, como delegado ou missionário. Assim, Dunn pergunta se a experiência de conversão de Paulo foi uma aparição do Ressuscitado e se ela foi distinta das suas experiências do Espírito e visões extáticas subsequentes (DUNN, 1997, p. 99-100). ${ }^{\text {? }}$

Dunn está buscando identificar se a experiência de Paulo é distinta de suas outras visões e revelações, e se ela deve ser descrita como uma aparição do Ressuscitado. Segundo ele, o próprio Paulo vê uma clara distinção entre elas. Sendo justificado ou não, a aparição de Jesus para ele foi algo único na sua própria experiência. Primeiro, Paulo coloca a sua experiência como uma das aparições que formam a base e substância da proclamação cristã. Aliás, ele a coloca como a última, destacando que ele não sabe de nenhuma outra aparição nem para ele e nem para outra pessoa. A aparição a ele foi a última e ele é o último dos apóstolos. Dunn também pensa que, com abortivo em 1 Co 15,8, Paulo ressalta que o seu nascimento na fé em Cristo foi prematuro e repentino, antes de ele estar pronto - ele não tinha andado e sido comissionado por Jesus como os outros -, permitindo ele entrar no círculo de apóstolos antes do tempo de as aparições terem se cessado. Isso fortalece o ponto que ele a viu como algo único diante das suas outras experiências, o que faz com que ele se sinta justificado em afirmar ser um apóstolo. Com o "eu vi" de 1 Co 9,1, Paulo ressalta um evento que ocorreu no passado e do qual os efeitos ainda estão em atuação, um evento que fez possível e constituiu Paulo como um apóstolo. Essa experiência inicial determinou o resto da sua vida, sendo distinta das demais. Enfim, Paulo deliberadamente evita usar a palavra "visão" para descrever a sua experiência em Damasco,

9 Segundo J. Lindblom, os relatos da conversão de Paulo em Atos têm todas as marcas de uma visão extática (fenômeno de luz e som, estado subsequente de choque e a característica repentina e inesperada do evento). Ademais, as próprias descrições de Paulo (revelação e ver) são consistentes com essa compreensão (DUNN, 1997, p. 100). 
distinguindo-a das suas experiências extáticas que ele cita em 2 Co 12. Mesmo descrevendo ambas como revelação, frente aos adversários de Coríntios, Paulo defende que a ressurreição envolve um corpo, enquanto os seus oponentes afirmam que não. Mesmo sendo familiar com ambas, ele distingue a aparição do Senhor ressuscitado, em corpo espiritual, das visões, revelações e outras experiências inspiradas pelo Espírito do interior. "A sua experiência na estrada de Damasco não foi simplesmente a primeira de muitas e muitas experiências do mesmo tipo; Para Paulo, ela foi a última de um número limitado e de um tipo único" (DUNN, 1997, p. 100-103, itálico do autor, tradução nossa).

Dunn realiza uma discussão sobre a distintividade da experiência de conversão de Paulo em dois aspectos, na aparição e no comissionamento (DUNN, p. 104-114). A título de conclusão, ele afirma que a distintividade da experiência de Paulo em Damasco está tanto na sua natureza como uma aparição quanto no seu caráter como um comissionamento. Ele não precisava descrever em termos de ver, mas o fez honestamente quando necessário, pois foi assim que Jesus se manifestou a ele, algo que distingue a sua experiência das dos gnósticos (Cristo pneumático). Contudo, o seu ver Jesus, a aparição, não foi apenas uma aparição. Há algo a mais na sua percepção visionária de Jesus exaltado, assim como na dos outros apóstolos, que é um chamado à missão, que vem junto com a aparição (DUNN, p. 113-114).

Assim se torna claro que não foi o ver em si e nem o comissionamento em si que era distintivo para Paulo, mas a aparição como chamado, o encontro como comissão. O comissionamento não veio ao lado, à parte do ver. A aparição em si era o comissionamento. A revelação em si era $o$ evangelho. Com a aparição da divina glória veio a esmagadora convicção que esse era Jesus ressuscitado da morte, que aqui estava o evangelho escatológico de Deus para os judeus e para os gentios, que daqui em diante sua vida inteira deve ser dedicada à sua proclamação, custe o que custar (DUNN, 1997, p. 114, itálico do autor, tradução nossa).

Dunn afirma que parte da distintividade da experiência de conversão de Paulo está "no elemento do ver e do que foi visto" (1 Co 9,1; 15,8). Porém, devido a extensão semântica da palavra ver, indaga acerca do que ele teria visto, qual seria a natureza/tipo (kind) do "ver" (DUNN, p. 104, itálico do autor, tradução nossa).

As possibilidades seriam:

(a) percep̧̧ão mental, uma apreensão intelectual de alguma verdade ou entendimento. Isso se daria por meio da lógica, intuição ou revelação. Entretanto, Dunn vai contra essa linha, afirmando que a etimologia grega do "ser visto" sempre denota ver com os olhos; quem vê, realmente vê algo. Porém, ressalta que negar que ela seja apenas uma percepção da mente não quer dizer que ela não tenha uma dimensão mental subjetiva (DUNN, 1997, p. 104-105). 
(b) percep̧ção física, de ver um objeto presente ao sujeito no tempo e espaço através dos olhos físicos. Aparentemente as aparições dos evangelhos, sobretudo Lucas, possuem a intenção de relatar uma percepção física. Ao descrever em 1 Co 15 a sua experiência com a mesma palavra que descreve essas outras aparições, Paulo talvez tenha tentado dar a ela alguma objetividade. Porém, a subjetividade da experiência de Paulo não pode ser negada (em mim - Gl 1,16), pois ele próprio sublinha essa dimensão subjetiva da revelação e o seu impacto na sua vida. Ele está descrevendo a sua experiência de conversão como uma experiência subjetiva pessoal. Em Atos, todas as passagens que descrevem a conversão de Paulo só podem ser entendidas em termos subjetivos e visionários: uma visão do céu (At 26,19), mesmo que os seus companheiros tenham visto uma grande luz, apenas Paulo fica cego e escuta a voz do céu (At 22,6.9-11). Paulo teve um encontro pessoal, uma cristofania. Segundo Pannenberg, um evento assim deve ser compreendido como uma visão, pois se alguém vê algo que os outros presentes não veem, trata-se de uma visão. Dunn afirma que mesmo se for uma edição de Lucas, ela parte de uma boa tradição (2 Co 4,6). Segundo ele, não dá para negar a subjetividade da aparição para Paulo. Assim, o seu ver Jesus não pode ser descrito como uma percepção física (DUNN, 1997, p. 104-106).

(c) percep̧cão visionária, pode significar onde o ver está envolvido, mas a sua natureza é disputada. É colocado em questão se o ver ocorreria na mente de forma interna, de forma semelhante a um sonho, ou na projeção de imagens mentais, como acontece em algumas visões, ou se o visionário estaria vendo uma realidade externa, presente a ele, mas ausente aos demais. Dunn está certo de que Paulo viu algo, mas indaga o que ele teria visto e se havia algo para ser visto, algo externo a ele. Respondendo, afirma que a única resposta que Paulo nos permite dar é que ele viu Jesus. Porém, ele não descreve - e nem tenta descrever - o que ele viu. O exegeta questiona se haveria algo indescritível no modo de existência de Jesus que Paulo percebeu, para o qual não existe definição ou detalhes. Quando ele se defende a partir deste evento, Paulo não o elabora e nem o descreve, apenas o reivindica e destaca os efeitos que a sua conversão causou na sua vida. Paulo tinha convicção de que viu algo, e o passivo indica que a iniciativa está naquele que é visto, e não naquele que vê: Ele apareceu, mostrou-se ${ }^{10}$ para Paulo; este está vendo algo que lhe é dado para ver. Ele vê Jesus Cristo vivo dos mortos, o evangelho, as boas novas. Dunn afirma que o ver de Paulo aconteceu de maneira visionária, mas que para ele foi uma percepção real e um encontro com Jesus, embora tenha ocorrido em uma esfera da existência que não pode

10 "Mostrou-se" é o melhor termo que expressa as aparições, pois a iniciativa é do Ressuscitado. 
ser descrita devido às limitações da descrição visual. A aparição foi um ato revelador, mas o revelado foi o próprio Jesus Cristo. Por fim, a aparição não foi uma experiência extática, como uma visão ou uma revelação. Paulo era familiar com essas experiências, mas a sua conversão foi algo distinto. Em Damasco ele experimenta não apenas o poder, o Espírito de Deus, mas mais que isso, ele também percebe uma pessoa, o Cristo ressurreto (DUNN, 1997, p. 104-109).

Em resumo, Paulo estava convicto que Jesus estava vivo e havia aparecido para ele. Com a luz ofuscante que ele viu fora de Damasco nasceu sobre ele a inextinguível convicção que era Jesus que ele estava vendo - "a glória de Deus na face de Jesus Cristo" [2 Co 4,6]. Ele não poderia descrever mais que isso; mas ele pôde descrever até aí. Essa experiência foi sem comparação na sua vida subsequente; nem ele reconheceu experiência como a sua na de outros. As únicas experiências comparáveis foram as aparições do Ressuscitado aos primeiros apóstolos (DUNN, 1997, p. 109, itálico do autor, tradução nossa).

O outro aspecto significante da experiência de conversão de Paulo é o seu comissionamento apostólico e a dimensão escatológica presente nele. Como já destacado, Paulo menciona a sua experiência em Damasco sempre quando fala de sua mensagem ou de seu apostolado, e nunca como uma experiência de conversão como tal, como o princípio de sua vida e fé cristã. A ênfase está sempre no seu chamado (Gl 1,16; 1 Co 9,1; 15,8-11; 2 Co 4,4-6), que é para proclamar Jesus aos gentios, como o Filho de Deus e Senhor. A sua autoridade e a fonte do seu evangelho é a própria experiência da revelação. Isto é, não veio de memórias durante o ministério de Jesus, pois provavelmente nunca o encontrou. Ela vem do encontro com Jesus ressurreto. É claro que o seu pensamento teológico e o seu entendimento do evangelho foi se desenvolvendo, mas parte da aparição nas proximidades de Damasco. Também, o seu chamado apostólico contém uma tarefa escatológica, pois como a ressurreição de Jesus possui um significado escatológico (primeiro fruto) de que a ressurreição escatológica havia iniciado $(\operatorname{Rm} 1,4 ; 1$ Co 15,20.23), de que a colheita da ressurreição final e o Fim já começaram, Paulo parece ver a si mesmo como alguém que preenchia um papel essencial no fim da história da salvação, com o seu ministério para com os gentios. Ele até desejou pregar até os limites do mundo conhecido, na Espanha (Rm 15,28). O cumprimento de sua tarefa escatológica tem um significado escatológico crucial (Rm 11,15.25-26). Nesse sentido, segundo Dunn, o apóstolo também se viu compartilhando e cumprindo, com o seu sofrimento, o papel do Servo de Yahweh com Jesus (Cl 1,24). Essa experiência suplantou todas as outras. A revelação de Jesus Cristo suplantou a revelação da lei na vida 
de Paulo, o fariseu. Nenhuma outra experiência de Paulo tinha o significado epocal e escatológico para ele, que marcou o resto da sua vida, da qual tudo se seguiu. A revelação de Jesus Cristo que Paulo experienciou foi a primeira base e a autoridade final da sua nova fé e da sua compulsão escatológica, que moldou a sua vida e ministério. Esse é o outro aspecto da distintividade da sua experiência de conversão (DUNN, 1997, p. 110-113).

\section{As primeiras aparições e a diversidade dos seus relatos}

Então, Dunn inicia uma discussão buscando distinguir as diferenças entre a aparição para Paulo das mais antigas, partindo de dois pontos, o elemento visual e o elemento do comissionamento. Enquanto o ver de Paulo foi visionário, nem físico e nem material, num sentido de um objeto que possa ser examinado, os relatos dos evangelhos trazem uma imagem de natureza física. Embora tendo ainda algo misterioso, uma vez que ele aparece de repente dentro de portas fechadas (Jo 20,19.26), essas aparições são bem diferentes da que Paulo experimentou. A diferença principal está na intangibilidade e na tangibilidade dessas experiências de ver. As explicações propostas envolvem (a) um desenvolvimento dogmático, do físico/material ao visionário/espiritual, ou o contrário, (b) um desenvolvimento das aparições em narrativas com traços do Jesus terreno, do visionário a materialização lendária. (c) Uma outra alternativa é a de Lindblom de que haveria diferentes tipos de aparições, as terrenas (cristepifanias) antes de Pentecostes e as do céu (cristofanias), depois de Pentecostes. O exegeta afirma que, embora a segunda tendência (b) tenha mais evidências, a primeira (a) também é evidenciada (DUNN, 1997, p. 114-117).

Dunn discorre acerca do que tratamos no tópico anterior, da ideia de ressurreição no período intertestamentário, e discute sobre os textos menos sofisticados, que já referenciamos. Ademais, o exegeta também está certo de que houve um desenvolvimento interpretativo evidente no NT a respeito das aparições, o que demonstra, para além do que costuma ser admitido, uma complexidade no processo interpretativo nas tradições da ressurreição. Incluindo, por exemplo, o desenvolvimento de uma interpretação das aparições mais espiritual para uma mais física (DUNN, 1997, p. 117-120).

A compreensão de Dunn desse desenvolvimento é a seguinte: Primeiro, a confluência entre a descoberta do túmulo vazio e as aparições experienciadas por Pedro, "os dozes", e talvez as mulheres, trouxe a conclusão de que o corpo de Jesus havia sido ressuscitado da cova, por Deus. Uma vez que não havia na mentalidade deles uma distinção material entre ressurreição, 
ascensão e exaltação, eles criam que Jesus ressuscitou ao céu. Não há razões para duvidar que essa compreensão física da ressurreição continuou em Jerusalém. Segundo, com a propagação do evangelho em áreas mais helenistas, que possuem no seu pensamento uma aversão ao material, a compreensão da ressurreição do corpo físico de Jesus vira um motivo de desdém (At 17,32; 1 Co 15,12.35). Assim, a ideia do corpo ressurreto é redefinida e há um distanciamento da de que a carne era restaurada na ressurreição. Pelas evidências, isso ocorreu através de Paulo (1 Co 15,50), influenciado pelo pensamento grego, embora não tenha caído no dualismo entre corpo e espírito e nem tenha afirmado uma imortalidade da alma. "A carne não seria ressuscitada, mas o corpo seria" (DUNN, 1997, p. 120-121, itálico do autor, tradução nossa). ${ }^{11}$

O terceiro estágio vai na direção contrária ao desenvolvimento de Paulo, reafirmando a compreensão física. Isto é visto de forma clara nos relatos de Lucas. Porém, elas não são apenas um retorno à conceitualização primitiva do estado da ressurreição de Jesus. Elas destacam deliberadamente a tangibilidade física do corpo ressuscitado de Jesus. É uma materialização do sobrenatural, fazendo parte da tendência e do traço de Lucas de enfatizar a objetividade de experiências espirituais (Lc 3,22; 9,32; At 2,3). Nesse sentido, essa característica lucana está presente na materialização das narrativas das aparições. Essa ênfase na objetividade da ressurreição pode ter tido estimulada por uma tendência docética ou é, simplesmente, uma expressão do traço lucano (DUNN, 1997, p. 121-122).

Por fim, Dunn levanta a possibilidade de um quarto estágio presente no Evangelho de João. O evangelista enfatiza a tangibilidade do corpo ressuscitado, porém, Jesus não é descrito fazendo nada tão físico no capítulo 20, como comer, Aliás, no verso 17, Maria é desencorajada a tocá-lo. Tomé é até encorajado a tocar e sentir Jesus, mas não é relatado se ele fez isso. Segundo o exegeta, a implicação é que Tomé confessou a sua fé e dispensou provas físicas, pois a mera aparência de Jesus o venceu. Além disso, conforme o verso 20, a bem-aventurança é para quem crê mesmo não tendo visto. "Então, talvez, João 20 deve ser visto como uma forma ligeiramente recuada da tentativa ousada de Lucas de produzir prova tangível da realidade do corpo ressuscitado de Jesus" (DUNN, 1997, p. 122, tradução nossa).

11 Segundo Dunn (1997, p. 121, itálico do autor), essa distinção foi ousada, pois soma e sarx eram mais ou menos sinônimos; ambos se referiam ao corpo físico. Ela foi feita para apresentar a fé na ressurreição no contexto helenista. Assim, Paulo apresenta a ressurreição - e inclusive a de Jesus - como uma transformação do físico, e não uma restauração dele. Corpo espiritual e não corpo natural. Dessa forma, ele faz com que o conceito de ressurreição se desenvolva e seja mais sofisticado para o leitor grego, mantendo ainda a importância do pensamento hebraico da ressurreição como a ressurreição do homem inteiro, integral. 
Portanto, a resposta de Dunn ao porquê haveria várias diferenças entre as narrativas das aparições do Ressuscitado é que:

Os primeiros crentes entenderam as suas aparições do ressuscitado em termos bem mais físicos, enquanto Paulo entendeu o seu encontro com o Jesus ressurreto em termos bem mais espirituais - certamente, uma ressurreição corporal, mas um corpo espiritual. Lucas, por uma razão ou outra, reteve e sublinhou fortemente a visão original, e João talvez tenha concordado com alguma reserva (DUNN, 1997, p. 122, itálico do autor, tradução nossa).

Com essa diversidade dos relatos e narrativas, e com o nosso caminho investigativo percorrido até então, nos resta a dúvida do que teria sido testemunhado, o que teria sido visto e ouvido pelas primeiras testemunhas.

\section{As experiências das primeiras testemunhas do Ressuscitado}

Como já vimos, a experiência de Paulo foi um ver visionário que ele não era capaz de elaborar. Agora, Dunn busca compreender quais foram as experiências dos primeiros cristãos e como foram essas aparições que permitiram uma maior elaboração posteriormente. Segundo o exegeta, uma resposta possível sobre as mais antigas é que houve diferentes tipos de aparições. Porém, uma sugestão ainda mais plausível é que havia uma certa ambiguidade nelas: eventos em que um fato central, que Jesus ressuscitou, era indiscutível, mas que não tinha claridade nos detalhes, dando espaço para uma certa variedade de interpretação da realidade que foi testemunhada. Não é claro se Mt 28,16-20 é uma "cristepifania" ou uma cristofania, não podendo ser limitada nem numa nem noutra. Antes, a ambiguidade da percepção de Jesus nesse relato permite que ela seja entendida como uma ou como a outra. Além disso, ela também traz um aspecto do ver e do comissionamento. Esse ver traz uma sugestão de que a ambiguidade da aparição esteja em um ver visionário, como o de Paulo, que foi condicionado, embora não determinado, por fatores subjetivos. Isto é, para alguns dos doze a percepção foi mais clara, tangível e muito real, o que permitiu que eles a elaborassem em termos físicos, e para outros mais obscura e menos clara, sendo nesse caso confirmada pelo comissionamento, talvez também pelo testemunho de Pedro. A ambiguidade faz com que ela seja até dubitável para alguns (Mt 28,17), o que traz um elemento de eco histórico. Todos tiveram a convicção de terem visto Jesus (1 Co 15,5.11), porém alguns mais imediatamente na experiência, e outros não tão imediatamente (DUNN, 1997, p. 123-125).

Conforme o kerygma primitivo, a aparição a Pedro foi a primeira de todas (1 Co 15,5; Mc 16,7; Lc 24,34). Ela foi um encontro decisivo e o nascimento 
do evangelho como o evangelho, um fundamento da tradição. Essa primazia é confirmada pelo protagonismo designado a ele, como liderança em Jerusalém, como pedra e possuidor das chaves do reino (Gl 1,18; At 1-5; Mt 16,18-19); porém, não há relatos que narram tal essa aparição. Lucas certamente a relataria se possível, e como não relatou, é provável que não houvesse alguma fonte desse evento disponível para ele. Isso sugere que Pedro não tentou elaborar a sua experiência, nem em termos visionários e nem materialista. Logo, ela deve ter sido como a de Paulo: ele não tinha dúvida que Jesus apareceu para ele, mas ele não podia descrever mais sobre o que ocorreu. 1 Co 15,5 talvez traga a sugestão de um aspecto de ver e de ser comissionado. No final, Pedro apenas podia afirmar que Jesus havia ressuscitado e aparecido a ele e demonstrar esse fato pelas suas atitudes e condutas, pois é provável que a sua experiência da aparição tenha sido "algo tão intensamente pessoal que seu pleno caráter e significância não pôde ser concebido em palavras, e apenas seria perdido na narração. [...] Dizer qualquer coisa a mais era dizer menos" (DUNN, 1997, p. 125-126, itálico do autor, tradução nossa). Segundo Dunn (1997, p. 392, n. 128), talvez a mesma coisa possa ser dita da aparição experienciada por Tiago, irmão de Jesus.

Prosseguindo, Dunn fala sobre as discussões sobre a historicidade das narrativas das aparições às mulheres, mas não corrobora com a afirmação de que elas seriam um desenvolvimento legendário, para ligar a tumba vazia às aparições; se fosse o caso, eles usariam uma figura masculina, como Pedro. $\mathrm{O}$ autor afirma que se temos subsídio que elas descobriram a tumba vazia, também devemos permitir a possibilidade e a probabilidade delas terem tido uma ou algumas experiências visionárias na tumba ou ao redor dela. Perguntando o que elas teriam visto, afirma que o elemento da ambiguidade aqui é bem forte, pois os diversos relatos trazem diferentes detalhes (Mc 16,5; Lc 24,4.23; Mt 28; Jo 20,12-18), tanto de quem elas viram, um, dois anjos ou Jesus, como das características desses anjos e de quais mulheres tiveram a experiência. Assim como também há uma ambiguidade no tocar em Jesus, sendo que em Mateus uma segura nos seus pés e, em João, mesmo tangível, Jesus não permite que Maria o toque. As narrativas também trazem um aspecto de que elas tiveram terror e fascínio e que elas ou não disseram nada sobre o que ocorreu ou que os demais não acreditaram no testemunho delas (DUNN, 1997, p. 126-127).

De tudo isso emerge uma imagem plausível e coerente: as mulheres que visitaram o túmulo tiveram uma experiência visionária na qual elas mesmas não estavam certas num primeiro momento de quem ou o que elas viram. Elas vieram a reconhecer a visão como uma aparição de Jesus (talvez com base na experiência de Pedro), mas os relatos delas eram tão confusos e desconcertantes que não foram levados seriamente 
pelos outros discípulos. Alguns os ignoraram, pois de qualquer forma o testemunho de mulheres não contava; alguns os interpretaram como "uma visão de anjos"; alguns os aceitaram como uma aparição genuína do Senhor ressuscitado. Nos dois últimos casos, as tradições que resultaram sofreram várias elaborações que as deixaram como as temos atualmente (DUNN, 1997, p. 127-128, tradução nossa). ${ }^{12}$

Diante das evidências disponíveis, Dunn afirma que as experiências das aparições às mulheres, à Pedro e "aos dozes" apontam para experiências visionárias intensamente pessoais e ambíguas, das quais havia uma certeza: de que eles haviam visto Jesus ressuscitado da morte. O exegeta destaca que, mesmo não sendo tão claro num primeiro momento, também há um elemento de comissionamento nessas aparições, assim como em Paulo. Porém, parece que tiveram nelas uma reflexão e revelação posterior, desenvolvimentos teológicos. Assim, não é claro se houve um comissionamento efetivo nas aparições iniciais aos judeus. O tom escatológico da comissão que há em Paulo é menor ou quase inexistente aqui. Contudo, depois de uma discussão sobre a questão, ele conclui que dificilmente se pode negar que houve um elemento de comissionamento nas primeiras aparições, mesmo que em uma forma menos elaborada (DUNN, 1997, p. 128-130).

Em muitos casos a experiência de ver Jesus ressuscitado da morte também foi o começo de uma compulsão de fazer a sua ressurreição conhecida. Nem todas as experiências tiveram esse efeito [...]. Mas aqueles que emergiram como líderes da seita nascente estavam convictos que o Jesus ressuscitado havia os comissionado pessoalmente e as suas convicções foram aceitas pelos demais (DUNN, 1997, p. 130, itálico do autor, tradução nossa).

Acerca das características das primeiras aparições em comparação com a de Paulo, Dunn afirma que elas foram a mesma experiência, embora diferentes. A mesma em relação à realidade encontrada, o Jesus ressuscitado. Porém, são diferentes porque a sua aparição causou impactos diferentes em pessoas diferentes. "Em resumo, as três características mais primitivas da aparição do Ressuscitado para Paulo são um ver visionário, um elemento de dúvida e medo, e um senso de obrigação de fazer a visão conhecida". Todavia, para os demais, elas não ocorrem exatamente da mesma maneira, pois esses três aspectos da aparição à Paulo não se repetem em todas, ocorrendo em combinações diferentes. "Mas em todos os casos registrados a convicção consequente é firme e certa: 'Jesus ressuscitou; ele apareceu a mim/nós"” (DUNN, 1997, p. 131, itálico do autor, tradução nossa).

12 Segundo Vermes (2013, p. 131), a inclusão de figuras masculinas em João e Lucas serviu para respaldar e evidenciar o relato das mulheres, pois não havia credibilidade no testemunho feminino naquela sociedade masculina judaica. Aludindo à Lc 24,11, ressalta a classificação desdenhosa, desvario (lêros), às palavras delas. 
Por fim, na questão de se as aparições teriam sido todas experiências integralmente da mente, possibilidade que confessa não poder ser totalmente descartada, Dunn confessa que, para ele, "a explicação mais satisfatória é que foi Jesus que eles viram - Jesus vivo dos mortos, se fazendo conhecido a eles em um modo de existência que transcendia as limitações do tempo e espaço" (DUNN, 1997, p. 131-132, itálico do autor, tradução nossa). ${ }^{13}$

Dunn traça três pontos conclusivos no seu capítulo acerca das aparições:

$\left[1^{\circ}\right]$ Quais foram as experiências espirituais que deram à luz ao cristianismo? Nossa primeira resposta tem sido em termos das aparições do Ressuscitado, e não poderia ser de outra forma. No começo do cristianismo nós encontramos um número de experiências nas quais aqueles envolvidos acreditaram que Jesus havia aparecido a eles. Não devemos permitir que a nossa familiaridade com a crença cristã na ressurreição de Jesus suavize ou abafe a extraordinária ousadia dessa afirmação. Certamente, "a ressurreição de Jesus" era uma metáfora (Pannenberg), uma maneira de interpretar a experiência deles (Marxsen). Mas a interpretação nos conta algo sobre a experiência interpretada; e uma experiência que levou os judeus do primeiro século à conclusão que um único indivíduo já havia antecipado a ressurreição geral da morte, por mais breve que seja o intervalo, deve ter sido uma experiência bem convincente - uma experiência que apontou com muita força para aquela interpretação. O elemento visionário e subjetivo de suas experiências certamente deixou as interpretações e a fé deles abertas para algumas questões. A possibilidade de que elas foram apenas visões subjetivas não pode ser descartada. Mas é também possível que Jesus realmente viveu novamente para além da morte em uma dimensão e modo de realidade que apenas pode ser desvelada ${ }^{14}$ em alguma forma de percepção visionária. Certamente, é significante que os estratos mais antigos da tradição prestam testemunho para a dificuldade

13 Dunn chega nessa conclusão pessoal fazendo o raciocínio que se segue. Ele esclarece que uma auto ilusão ou alucinação em massa, por fatores psicológicos e subjetivos, não podem ser descartadas devido à ambiguidade da experiência religiosa. Porém, afirma que a balança pesa mais para um outro lado, deixando de lado questões como a tumba vazia. O exegeta defende que os primeiros crentes estavam absolutamente convencidos de que viram Jesus ressuscitado, até mesmo os que duvidaram num primeiro momento. Para ele, essa convicção é um fato incontestável. Então, indaga sobre o porquê de eles assumirem terem visto o Jesus ressuscitado, e não um anjo, uma visão dele morto ou uma visão dele sem carne, conforme as expectativas apocalípticas (Mc 8,38-9,8; 14,62; Mt 28,2-4; At 1,9-11). Assim, advoga que "deve ter tido algo muito convincente sobre as aparições para que conclusões tão extravagantes fossem tiradas, para não dizer ridículas e ultrajantes” (DUNN, 1997, p. 131-132, tradução nossa). É por isso que Dunn pensa que eles teriam realmente visto Jesus, o que corroboramos. As impactantes e reais experiências das aparições do Ressuscitado, realidade que vão além do espaço e do tempo, mesmo manifestando nessas dimensões, explicam melhor tudo o que ocorreu e o que se sucedeu.

14 Optamos por traduzir “disclosed” por desvelada do que por revelada. Essa preferência se dá pela ambiguidade da palavra revelação, que pode tanto significar o descobrir de algo velado (revelação) quanto o recobrir do mesmo (revelação). Por isso, para referir-se com mais precisão ao que é usualmente designado como revelação, em alguns momentos usaremos o termo desvelação, como alusão ao processo do desvelar de algo velado. 
de conceitualizar as aparições (ambiguidade, "corpo espiritual" - o que é isso?). Ainda, o fato permanece que a conclusão que veio a eles foi que era o próprio Jesus que havia encontrado com eles. O $̋ \varphi \theta \eta$ [apareceu; mostrou-se] de 1 Co 15,5-8 não especifica um modo uniforme da aparição, mas implica que, apesar de todas as ambiguidades e diferenças de conceitualização, todos esses listados estavam convictos de que foi a mesma realidade que eles tinham experienciado - um encontro com alguém diante deles - e que essa [realidade] era o mesmo Jesus crucificado, morto e enterrado há alguns dias ou semanas (DUNN, 1997, p. 132-133, itálico do autor, tradução nossa).

[2] Em uma parte desses encontros com o Ressuscitado, das vivências das aparições, o elemento mais convincente foi a comissão, o chamado que veio junto com a experiência visionária. A própria aparição requisitava das testemunhas a propagação aos outros. Similarmente aos grandes profetas, todos os apóstolos experienciaram um chamado visionário que foi determinante em suas vidas dali em diante (DUNN, 1997, p. 133).

$\left[3^{\circ}\right]$ Dunn também desenvolve um corolário relacionado às discussões modernas sobre a ressurreição de Jesus da experiência de Paulo. Segundo ele, embora Paulo seja familiar com outras experiências, como as suas posteriores, ele via a experiência de sua conversão como algo distinto delas. Isso inclui visões, manifestações carismáticas e a experiência do "Cristo em mim". Logo, ele não aceitaria a afirmação de que sua experiência teria sido apenas uma visão subjetiva (Strauss, etc.) ou que Jesus ressuscitou ao querigma (Bultmann). Ele conhece experiências assim, mas trata a aparição com singularidade e, mesmo que a sua distinção seja rejeitada, ela não pode ser ignorada (DUNN, 1997, p. 133-134, tradução nossa).

\section{Ponderações teológicas sobre a ressurreição}

Habitualmente, com uma leitura literalista da Bíblia, o imagético pietista acerca da ressurreição constitui-se de uma ideia inteiramente objetivista, fisicista e materialista. Por outro lado, segundo uma compreensão contemporânea, ela teria sido a expressão de uma vivência e/ou convicção subjetiva. A experiência desta última pode ser denominada de real-subjetiva. ${ }^{15}$ Em con-

15 Nesse sentido, encontramos Edward Schillebeeckx (1914-2009) e Vermes. Nogueira (2020, p. 62-63) também parece ter uma compreensão subjetiva da ressurreição. Sobre a questão em Schillebeeckx, indicamos a sua obra Jesus, a história de um vivente (2008) e o artigo de Valdete Guimarães (2018). Em Vermes, o seu livro Ressurreição (2013). As perspectivas subjetivas são instigantes. Entretanto, não as assumimos como uma explicação dos relatos neotestamentários, pois parecem incompletas e limitadas - similarmente às objetivas. Como elucida Wright, sem algum evento como os descritos nos capítulos finais dos Evangelhos ou no começo de Atos, alguns elementos únicos dos primórdios do cristianismo não são explicáveis. "Não parece ser muito plausível descartar esses relatos únicos como a projeção a-histórica da 'fé cristã primitiva', e pode-se argumentar que é impossível explicar o nascimento dra- 
traste, a perspectiva dunniana pode ser classificada como histórico-perceptiva, pois envolve percepções visionárias, auditivas (e tacto-físicas?).

Mas o que é ou teria sido a ressurreição? Etimologicamente, segundo Wright:

"Ressurreição" (grego anastasis) denota o retorno ('ressurgir', 'levantar-se') à vida corpórea de uma pessoa ou pessoas que morreram corporalmente. Não significa "vida após a morte", mas uma nova vida [do] outro lado de qualquer existência imediata post-mortem que possa existir (WRIGHT, 2011, p. 444, tradução nossa).

\section{Da crença escatológica no judaísmo antigo, Bingemer afirma que}

não importando quão largo o espectro possa ter sido das muitas posições diferentes, que os judeus tenham assumido, "ressurreição" sempre denota não um termo para "vida após a morte" em geral, mas reintegração da vida, desde já e em sua totalidade (BINGEMER, 2008, p. 120).

Wright e Bingemer ratificam que a ressurreição é a vida reintegrada após a real morte.

Ela não é nem uma vida após a morte (inferno, purgatório e céu), e nem uma simples revivificação, uma simples volta à vida física anterior. ${ }^{16} \mathrm{~A}$ ressurreição é tanto uma reencarnação plenificada de sua humanidade ${ }^{17}$ como a reintegração de Jesus Cristo na divindade trinitária, ${ }^{18}$ realidade na qual a morte não tem mais poder. Jesus ressurreto é plenamente humano, com toda a sua existência como pessoa ainda mantida. Porém, agora a sua existência, embora ainda corpo/carne, é também plenamente pneumática. Isto é, na sua integralidade, Jesus Cristo é corpo/carne e Espírito. É ainda Deus encarnado na história, mas também o humano presente no e em toda expansão do espaço-tempo e além, como também na divindade trinitária.

mático do movimento cristão, seguindo a vergonhosa morte de Jesus, a menos que a reivindicação de que ele tenha ressuscitado seja bem fundamentada" (WRIGHT, 2011, p. 445, tradução nossa). Ainda assim, acreditamos que uma experiência e convicção subjetiva do Ressuscitado pode ser vivenciada após as experiências originárias, inclusive na contemporaneidade.

16 José Antonio Pagola (1937) ressalta que “o evangelho de João não confunde a 'revivificação’ de Lázaro, que saiu do sepulcro 'tendo os pés e mãos atados com faixas e o rosto envolto num sudário', com a ressurreição de Jesus, que deixa no sepulcro 'os panos de linho e o sudário’. Lázaro retorna a esta vida cheia de escravidões e travas. Jesus, pelo contrário, entra no país da liberdade e da luz" (PAGOLA, 2014, p. 495, n. 15).

17 Após perecer em sua encarnação, estando morto por alguns dias, ao viver novamente o Nazareno reencarna, assume novamente a sua carne e a integralidade da sua existência humana, retomando a seu ser encarnado.

18 Depois de esvaziar-se totalmente (kénosis), assumindo integralmente a existência humana e padecendo nessa, o Nazareno agora, reencarnado e ressuscitado, se reempossa da sua divindade e reintegra a alteridade trinitária, a trinitariedade. 
É certo que os primeiros cristãos tinham certeza que vivenciaram, viram e ouviram Jesus após a sua morte. É indubitável que eles tiveram tais experiências. Como vimos e corroboramos, Dunn afirma isso. Igualmente, nessa linha encontramos o ponto de vista de Ed Parish Sanders (1937): "Que os seguidores de Jesus (e mais tarde Paulo) tiveram experiências da ressurreição é, na minha opinião, um fato. Que realidade originou as experiências eu não sei” (SANDERS, 1993, p. 280, tradução nossa). Ou seja, a experiência religiosa do Ressuscitado foi real para eles, assim como é para os cristãos posteriores. O que pode ser colocado em dúvida é se essa realidade da experiência é "real" ou não, ou sobre sua natureza e tipo. Isto é, a ressurreição pode até ser negada, mas não a experiência dela. Todavia, crer nela é uma questão de fé.

Quanto à realidade que está por trás dessas experiências, acerca da qual Sanders conserva-se em aporia, corroboramos com Dunn que era Jesus, agora em um estado de existência transcendente, que está para além das limitadas dimensões do espaço-tempo. Em ousadia, dizemos que os primeiros seguidores vivenciaram, viram e ouviram, uma manifestação trinitária, da pessoa humana e divina de Jesus, mostrando-se aos seus na nossa realidade. É Jesus Cristo, o homem-divino que transcende a nossa realidade, desvelando aos seus a sua nova realidade e que está sempre presente, e também que Deus continua fiel ao projeto do Reino.

Então, a experiência de encontro com o Ressuscitado não é apenas um encontro objetivo ou subjetivo, mesmo tendo traço de ambos. Como pensa Dunn, é uma experiência visionária. É o enxergar, ouvir (e tocar?) uma realidade, alguém que mostra-se.

É como ver a luz tabórica, a luz incriada de Deus, a luz da transfiguração de Jesus. Essa era experienciada e vista pelos hesicastas, monges do Monte Atos. Respondendo algumas acusações do monge Barlaão de Calabria (aprox. 1290-1348) a eles, Gregório Palamas (aprox. 1296-1357/1359), monge do monte e, posteriormente, arcebispo de Tessalônica, elabora uma teologia mística dessa experiência (ELIADE, 1984).

Palamas não teve dificuldades em demonstrar que na Bíblia se menciona, em cada etapa, a luz divina e a glória de Deus e que o próprio Deus é chamado de luz. [...] Para Palamas, escreve Vladimir Lossky [(1903-1958)], “a luz divina é um dado da experiência mística. É o caráter visível da divindade, das energias pelas quais Deus se comunica e se revela aos que têm purificado os seus corações". Essa luz divina e deificadora é a graça. [...] Para ele, a luz é própria de Deus por natureza, existe fora do tempo e do espaço e se fez visível nas teofanias do Antigo Testamento (ELIADE, 1984, s/l, tradução nossa). 
$\mathrm{Na}$ transfiguração (Mt 17,1-8; Mc 9,2-8; Lc 9,28-36) e nas aparições, os seguidores de Jesus conseguem ver uma realidade para além da realidade. É claro que são experiências distintas, uma é de Jesus antes de sua morte, a outra é dele ressuscitado. Mas o caminho é o mesmo: o enxergar das energias divinas.

As experiências das aparições não são necessariamente experiências extáticas. Pode até ser que alguma tenha sido, com o êxtase como caminho. Porém, as experiências vivenciadas a partir da desvelação do Ressuscitado vão além dessas.

As percepções presentes nessas experiências, o ver, o ouvir (e o tocar?) Jesus Cristo ressuscitado, que desvela-se, que mostra-se, são extraordinárias. Por meio dessas, de percepções e sensibilidades extraordinárias, é possível vislumbrar e assimilar a realidade em sua plenitude e transcendência, que também está presente no tecido espaço-tempo, mas que também está além das dimensões conhecidas de nossa realidade e da nossa intelectualidade. Por isso, essa apreensão impactante é apenas parcial e limitada, pois a essência do Ressuscitado nos escapa. Apenas experienciamos as suas energias manifestadas.

Por fim, é essencial ressaltar dois pontos sobre o sepulcro vazio e o corpo de Jesus. Primeiro, conforme pontua Dunn, é provável que os primeiros discípulos viram no corpo de Jesus morto e no de sua nova vida uma íntima correlação: "que a sua carne não tinha sido permitida a se decompor e apodrecer - que o seu corpo tinha sido de fato, de forma bastante literal, ressuscitado da morte" (DUNN, 1997, p. 120, tradução nossa). Entretanto, mesmo se o sepulcro não estivesse vazio, se o corpo morto de Jesus estivesse lá, a fé na ressurreição não seria atingida. Isso porque a fé no Ressuscitado parte da experiência religiosa de desvelação. É claro que o testemunho dele estar vazio enriquece e causa um impacto na tradição da ressurreição. Mas a sua ausência não eliminaria a crença e a experiência. Nas cirúrgicas palavras de Bingemer (2008, p. 123), "a teologia não trabalha com provas e evidências empíricas, mas com a revelação de Deus acolhida pela fé humana. E é nessa linha que os textos neotestamentários vão abordar a ressurreição de Jesus".

Segundo, se o corpo físico no qual viveu a sua vida e ministério tivesse se decomposto e apodrecido na tumba, e ainda que os restos mortais de Jesus fosse encontrado naquela época ou hoje, ele não refutaria a ressurreição de Jesus. ${ }^{19}$ Certamente, isso seria um paradoxo e um mistério. Mas a fé é composta por ambos. Seria um paradoxo semelhante ao clássico e antigo Navio de Teseu, ou das renovações periódicas das células humanas, que ocorrem

19 Por causa disso, uma tentativa de provar empiricamente a ressurreição de Jesus para fins apologéticos, além de impossível, é igualmente banal e sem sentido. 
continuamente, mas que não alteram as identidades dos indivíduos. Se o corpo/carne físico de Jesus não tivesse sofrido a ressurreição e fosse encontrado, seria o corpo cadavérico dele. Simultaneamente, aquele que foi desvelado e visto pelos primeiros cristãos continuaria a ser o corpo/carne pneumático do Ressuscitado, que transcende as limitações da nossa realidade (espaço-tempo).

\section{Conclusão}

É na confluência entre um estado existencial de fracasso, desnorteamento e fuga, e num pano de fundo religioso que continha em sua imagética a esperança escatológica de uma intervenção divina e uma recompensa aos oprimidos, que os primeiros cristãos experienciaram aparições de um homem que havia morrido, o mesmo que eles tinham seguido e, posteriormente, abandonado quando o seu aprisionamento e crucificação. $\mathrm{Na}$ amargura, esses homens e mulheres encontram Jesus, ressuscitado por Deus e pelo Espírito, efetivando a expectativa escatológica do período, mas de uma forma inesperada.

Em uma perspectiva mais recente, a partir dos pilares das pesquisas recentes de Dunn sobre o Jesus histórico, sintetizadas em Jesus em nova perspectiva (2013), e em interface com a com a pesquisa realizada até aqui, poderíamos concluir algumas coisas, mesmo que sumariamente. Dunn defende que a existência história de Jesus é um fato inquestionável, e que o cristianismo ao longo da história só pode ser explicado com esse e com um outro fato, de que ele suscitou e deixou um impacto com a sua missão. Ambos são dados históricos sólidos e inquestionáveis. Com sua missão, Jesus "causou um impacto indelével nos seus discípulos. [...] Evidentemente, o que ele disse e fez sensibilizou profundamente muitas pessoas, e esse impacto ressoou ao longo da história" (DUNN, 2013, p. 27-28).

Nada obstante, não só a sua missão e vida antes de sua morte causou um impacto. A experiência das aparições como ressurreto também impactou a vida dos seus seguidores de uma forma assustadoramente intensa. Os relatos diferentes e diversos que temos das aparições do Ressuscitado são testemunhos, lembranças comunitárias, provavelmente transmitidas de forma oral, das experiências religiosas e reais que os discípulos tiveram de Jesus Cristo ressuscitado. Esses relatos não podem ser analisados como objetos empíricos. Antes, nascem de um impacto indelével causado por Jesus, pela iniciativa de Deus, se mostrando e lhes dando uma missão. Os relatos da ressurreição são testemunhos - desenvolvidos ou não - da experiência religiosa de ter tido um encontro com Jesus vivo, mesmo depois de sua morte, das percepções de ver, ouvir (e tocar?) o Nazareno ressuscitado em uma dimensão transcendente, ainda que sempre presente na história, sendo desvelada aos seus. 


\section{Referências bibliográficas}

BARTH, Gerhard. "Ele morreu por nós": a compreensão da morte de Jesus Cristo no Novo Testamento. São Leopoldo: Sinodal, 1997.

BINGEMER, Maria C. L. Jesus Cristo: servo de Deus e Messias glorioso. São Paulo; Valência: Paulinas; Siquem, 2008. (Coleção livros básicos de teologia, 8).

DUNN, James D. G. Jesus and the Spirit: a study of the religious and charismatic experience of Jesus and the first Christians as reflected in the New Testament. Grand Rapids: Eerdmans, 1997.

DUNN, James D. G. Jesus em nova perspectiva: o que os estudos sobre o Jesus histórico deixaram para trás. São Paulo: Paulus, 2013.

ELIADE, Mircea. Palamas y la luz tabórica. Ecclesia, Extracto de Mefistófeles y el andrógino.

Barcelona: Labor, 1984. [Disponível em < http://www.ecclesia.com.br/biblioteca/teologia/ mircea-eliade-palamas-y-la-luz-taborica.html $>$. Acesso em: 31 maio 2021].

GUIMARÃES, Valdete. Traços da cristologia narrativa de Schillebeeckx. Teocomunicação, Porto Alegre, v. 48, n. 2, p. 351-361, jul./dez., 2018.

NOGUEIRA, Paulo. Breve história das origens do cristianismo. Aparecida: Santuário, 2020.

PAGOLA, José A. Jesus: aproximação histórica. Petrópolis: Vozes, 2014.

SANDERS, Ed. P. The historical figure of Jesus. New York: Penguin, 1993.

SCHILLEBEECKX, Edward. Jesus, a bistória de um vivente. São Paulo: Paulus, 2008.

SOARES, Elizangela A. Variacõos sobre a vida após a morte: desenvolvimentos de uma crença no judaísmo do Segundo Templo. 2006. Dissertação (Mestrado em Ciências da Religião).

Programa de Pós-Graduação em Ciências da Religião, Universidade Metodista de São Paulo, São Bernardo do Campo, 2006.

STAUSBERG, Michael. Hell in Zoroastrian history. Numen, Leiden, v. 56, n. 2/3, p. $217-$ 253, 2009.

VERMES, Geza. Ressurreição: história e mito. Rio de Janeiro: Record, 2013.

WRIGHT, Nicholas T. Resurrection. In: McFARLAND, Ian A. et al (eds.). The Cambridge dictionary of Christian theology. Cambridge: Cambridge University Press, 2011. 